\title{
IMPACTS OF THE APPLICATION OF SWINE WASTEWATER IN PERCOLATE AND IN SOIL CULTIVATED WITH SOYBEAN
}

\author{
CACEA F. MAGGi ${ }^{1}$, PAULO S. L. DE FREITAS ${ }^{2}$, SILVIO C. SAMPAIO ${ }^{3}$, \\ JONATHAN DIETER ${ }^{4}$
}

\begin{abstract}
The aim of this study was to evaluate the possible impacts caused in the soil and in the percolate in lysimeters of drainage with application of different rates of swine wastewater (SW) during the cycle of soybean culture and to assess the productivity of it. The experiment was conducted at the Agricultural Engineering Experimental Center of UNIOESTE. The soil was classified as typical Distroferric Red Latosol. There were twenty-four drainage lysimeters in the area in which the soybean was cultivated, cultivar CD 214. Four SW depths $(0 ; 100 ; 200$ and $300 \mathrm{~m}^{3} \mathrm{ha}^{-1}$ ) were applied to the soil seven days before the sowing in a single application combined with two mineral fertilizations in the sowing (with and without recommended fertilization during sowing), and three repetitions per treatment. It was realized three collections of percolate in each experimental portion, the first was conducted 40 days after sowing (DAS); the second at 72 DAS, and the third at the end of crop cycle (117 DAS). It was evaluated in the percolate the $\mathrm{pH}$, calcium, magnesium, potassium, phosphorus, and total nitrogen. Based on the results, it was possible to observe that the level of $\mathrm{K}, \mathrm{P}$ and $\mathrm{N}$ in the soil increased according to the increase of SW rates. The levels of $\mathrm{K}$ and $\mathrm{P}$ in the percolate were higher for higher rates of SW. The productivity was not influenced by the application of SW or by fertilization.
\end{abstract}

KEYWORDS: lysimeters, effluent, soil pollution.

\section{IMPACTO DA APLICAÇÃO DE ÁGUA RESIDUÁRIA DE SUINOCULTURA NO PERCOLADO E NO SOLO CULTIVADO COM SOJA}

RESUMO: Este trabalho teve como objetivos avaliar os possíveis impactos causados no solo e no percolado em lisímetros de drenagem com a aplicação de diferentes taxas de água residuária de suinocultura (ARS) durante o ciclo da cultura da soja, bem como avaliar a produtividade da mesma. Conduziu-se o experimento no Núcleo Experimental de Engenharia Agrícola da UNIOESTE, cujo solo foi classificado como Latossolo Vermelho distroférrico típico. Na área, havia vinte e quatro lisímetros de drenagem, nos quais se semeou a cultura da soja, cultivar CD 214. Foram aplicadas ao solo quatro lâminas de $\operatorname{ARS}\left(0 ; 100 ; 200\right.$ e $\left.300 \mathrm{~m}^{3} \mathrm{ha}^{-1}\right)$ sete dias antes da semeadura, em uma única aplicação, combinadas com duas adubações minerais na semeadura (com adição e sem adição da adubação recomendada na semeadura) e três repetições por tratamento. Realizaram-se três coletas do percolado em cada parcela experimental, a primeira aos 40 dias após a semeadura (DAS), a segunda aos 72 DAS e a terceira no final do ciclo da cultura (117 DAS). Avaliaram-se no percolado e no solo, o pH, cálcio, magnésio, potássio, fósforo e nitrogênio total. Com base nos resultados, observou-se que os teores de K, P e $\mathrm{N}$ no solo aumentaram de acordo com o aumento das taxas de ARS. As concentrações de $\mathrm{K}$ e $\mathrm{P}$ no percolado foram maiores para taxas mais elevadas de ARS. A produtividade não foi influenciada pela aplicação de ARS e pela adubação.

PALAVRAS-CHAVE: lisímetros, efluente, poluição do solo.

\footnotetext{
${ }^{1}$ Universidade Federal da Fronteira Sul, Câmpus de Laranjeiras do Sul, Laranjeiras do Sul - PR, Fone: (42) 36358659, cacea.maggi@uffs.edu.br.

${ }^{2}$ DAG/ UEM, Av. Colombo, 5790, Maringá - PR, Fone: (44) 3261-8916, pslfreitas@uem.br.

${ }^{3}$ RHESA/UNIOESTE, Rua Universitária, 2069, Cascavel, PR. Fone: (45) 3220-3262, Silvio.Sampaio@ unioeste.br.

${ }^{4}$ Universidade Federal do Paraná, Campus Palotina. 85950000 - Palotina, PR. Tel: (44) 32118586, jonathan_dieter@yahoo.com.br. Recebido pelo Conselho Editorial em: 26-8-2011

Aprovado pelo Conselho Editorial em: 4-11-2012
} 


\section{INTRODUCTION}

The generation of high volumes of waste in swine activity, the concentration of production around industries and the difficulty of proper management of these wastes by producers, cause environmental problems, with impacts ranging from the discomfort of the local population by the proliferation of insects and odors until health problems generated by soil and water sources.

Despite the pollution potential of swine wastewater $(\mathrm{SW})$, it contains macro and micro nutrients such as nitrogen, phosphorus, potassium, calcium, sodium, magnesium, iron, zinc, copper and others who may contribute to reduce the use of chemical fertilizers in crops. The use of SW can be effective as biofertilizer, if used properly (DOBLINSKI et al., 2010; SAMPAIO et al., 2010a; SAMPAIO et al., 2010b; CAOVILLA et al., 2010; SMANHOTTO et al., 2010; PELISSARI et al., 2009; DAL BOSCO et al., 2008).

FREITAS et al. (2004) evaluated the effect of four water depths and SW, gross and sieved on components of maize production (Zea mays L.). The concentrations of BOD were of $1,111 \mathrm{mg} \mathrm{L}^{-1}$ for gross wastewater and $1,072 \mathrm{mg} \mathrm{L}^{-1}$ for sieved wastewater. The authors found that the use of swine wastewater increased significantly the productivity, plant height, cob index, and cob weight, in which the productivity for treatments with wastewater was approximately $58 \%$ higher than the control.

QUEIROZ et al. (2004) evaluated the effect of intensive application of SW on chemical characteristics of a Red-Yellow Podzolic soil, cultivated with four different species of forage grasses at a rate of $800 \mathrm{~kg} \mathrm{ha}^{-1} \mathrm{~d}^{-1}$ of $\mathrm{BOD}_{5}$ and observed that the application of $\mathrm{SW}$ provided an accumulation of $\mathrm{P}, \mathrm{K}, \mathrm{Na}$ and $\mathrm{Zn}$ in soil at the $0-20 \mathrm{~cm}$ layer, whereas the concentrations of $\mathrm{Mg}$ and $\mathrm{Cu}$ decreased and of $\mathrm{Ca}$ remained the same.

ANAMI et al. (2008) studied the process of percolation of nitrate and phosphate ions in the soil column and found that the nitrate ion showed high potential for percolation, unlike what happened with the phosphate ion, which showed low potential for contamination. As calcium is absorbed more strongly than ammonia, potassium and magnesium, its percolation is not as intense and actually not much of concern in terms of losses.

DIETER et al. (2007) evaluated the quality of the soil leaching subjected to the application of SW and found that rates of electrical conductivity (EC) in the leaching increased with the increase of the application, without, however, presenting problems of contamination of the groundwater.

CAOVILLA et al. (2005) studied the percolation of nutrients in soil columns cultivated with soybeans and irrigated with swine wastewater and found that the nitrate presented higher mobility in the leaching process followed by the concentration of total salt and, subsequently, of potassium in proportion to the evaluated treatments. Generally, the treatment that showed $75 \%$ of wastewater revealed, in leaching, higher levels of nitrate, potassium and salts concentrations.

BARROS et al. (2005), evaluated the chemical characteristics of the soil due to the addition of swine wastewater and found that the rates of electrical conductivity in the soil showed an increase, with a minimum value of $108.6 \mathrm{dS} \mathrm{m}^{-1}$ in conditions of higher temperatures, and maximum of $166.66 \mathrm{dS} \mathrm{m}^{-1}$ at lower temperatures.

Given the context, this study aimed to assess the possible impacts on soil and percolate using drainage lysimeters and productivity of soybean culture, with the application of different rates of swine wastewater.

\section{MATERIAL AND METHODS}

The experiment was conducted in the Agricultural Engineering Experimental Center (Núcleo Experimental de Engenharia Agrícola - NEEA), of the State University of West Paraná (Universidade Estadual do Oeste do Paraná - UNIOESTE), Campus of Cascavel, located at km 95 BR 467, in Cascavel - state of Paraná (PR), Brazil, geographically located by the coordinates $24^{\circ} 48^{\text {' }}$ 
of south latitude and $53^{\circ} 26^{\prime \prime}$ of west longitude, average altitude of 760 meters. The climate is humid subtropical (Cfa), with average annual rainfall of $1,800 \mathrm{~mm}$, average temperature of $20{ }^{\circ} \mathrm{C}$ and average relative humidity of $75 \%$.

The soil experimental area was classified as typical Distroferric Red Latosol, with smooth to wavy relief and very clayey texture, with a composition of $5.90 \%$ of sand, $14.73 \%$ of silt and $79.37 \%$ of clay (EMBRAPA, 2006).

In the experimental area, four experiments with consecutive application of swine wastewater (SW) were previously conducted.

In the first experiment, the soybean culture was fertigated with SW via drip irrigation system in a protected ambient. After the first experiment, twenty-four drainage lysimeters were installed in the area and after the implementation of the lysimeters; a need to divide the area into blocks was verified as the parameters of soil fertility presented heterogeneity. In the second experiment, the SW effects of application (manual) in maize culture, in a protected ambient and with drip irrigation system to simulate rainfall were verified. In the next experiment, the effects of the applied SW on soybean culture in protected ambient, with rainfall simulation made by localized irrigation system were manually evaluated. In the fourth experiment, the effects of SW in the culture of black oats, in open environment and no irrigation system were evaluated. Further details regarding the first, second and third experiment can be seen in FRIGO (2008) PRIOR (2008), and SMANHOTTO (2008), respectively.

Samples of soil were collected from each lysimeter in the 0-60 cm layer. All samples were homogenized to form a single composite sample to perform the chemical analysis of the soil. Mineral fertilizer was determined based on the chemical analysis for the soybean crop. In Table 1 are presented the results of the chemical analysis of the soil in the experimental area.

TABLE 1. Result of the composed chemical analysis of soil collected at the lysimeters for fertilization.

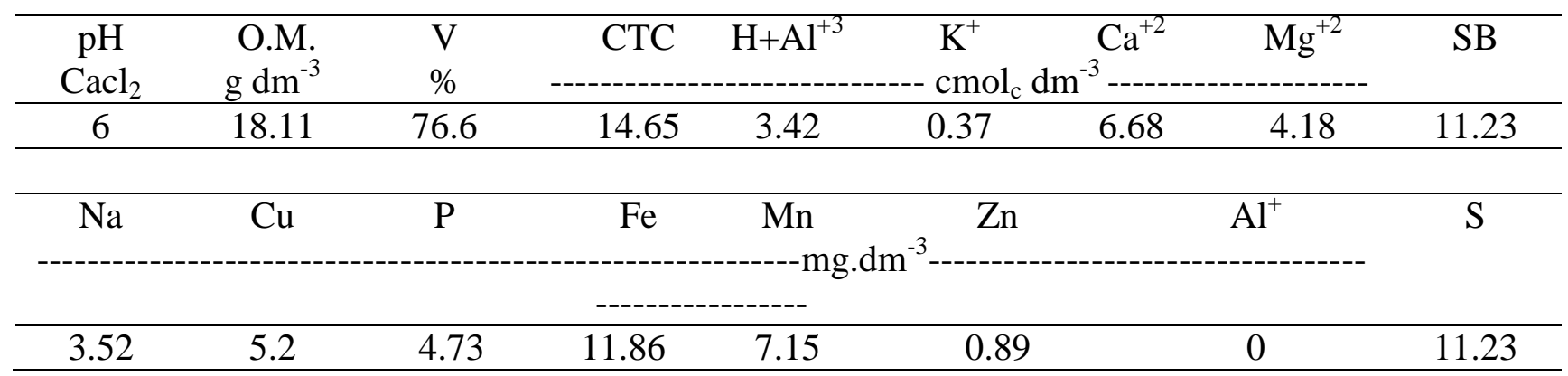

The 24 drainage lysimeters of the experimental area were constructed according to the methodology of FAO (1982). The lysimeter has volume of $1 \mathrm{~m}^{3}$ and area of $1.60 \mathrm{~m}^{2}$ (depth of $0.91 \mathrm{~m}$ and diameter superior than $1.43 \mathrm{~m}$ ) comprising an experimental portion.

In this study, the distribution of portions obeys the order established by PRIOR in 2005, and published in 2008 and the treatments were defined based on the study of SMANHOTTO in 2006, and published in 2008. The experiment was conducted during the period between November 2007 and April 2008.

The treatments are composed of four depths of SW applications of 100,200 and $300 \mathrm{~m}^{3} \mathrm{~h}^{-1}$ applied to the soil. Besides the SW depths, it was evaluated the effect of mineral fertilizer at the sowing (MF), applying $400 \mathrm{~kg} \mathrm{ha}^{-1}$ of NPK 0-20-10 formulate, according to the soil analysis presented in Table 1.

The collection of SW was performed on a farm where is installed an Integrated Biosystems Treatment, located in Toledo - PR. The collected wastewater was treated in a biodigester followed 
by a sedimentation tank and stabilization pond, and the output piping is the point of collection. The analysis is shown in Table 2.

TABLE 2. Characterization of the swine wastewater used in the experiment.

\begin{tabular}{|c|c|}
\hline Parameters & Values \\
\hline$\overline{\mathrm{pH}}\left(\mathrm{CaCl}_{2}\right)$ & 7.70 \\
\hline Electrical conductivity $\left(\mathrm{dS} \mathrm{m}^{-1}\right)$ & 5.43 \\
\hline Turbidity (NTU) & 393.00 \\
\hline $\mathrm{BOD}\left(\mathrm{mg} \mathrm{L}^{-1}\right)$ & 945.78 \\
\hline $\operatorname{COD}\left(\mathrm{mg} \mathrm{L}^{-1}\right)$ & 1322.13 \\
\hline Ammonia $\left(\mathrm{mg} \mathrm{L}^{-1}\right)$ & 466.45 \\
\hline Total nitrogen $\left(\mathrm{mg} \mathrm{L}^{-1}\right)$ & 887.00 \\
\hline Nitrate $\left(\mathrm{mg} \mathrm{L}^{-1}\right)$ & 2.18 \\
\hline Nitrite $\left(\mathrm{mg} \mathrm{L}^{-1}\right)$ & 2.25 \\
\hline Total Phosphorus (mg L $\left.{ }^{-1}\right)$ & 108.62 \\
\hline Soluble Orthophosphate $\left(\mathrm{mg} \mathrm{L}^{-1}\right)$ & 76.15 \\
\hline Potassium $\left(\mathrm{mg} \mathrm{L}^{-1}\right)$ & 462.11 \\
\hline Sodium $\left(\mathrm{mg} \mathrm{L}^{-1}\right)$ & 26.00 \\
\hline Calcium $\left(\mathrm{mg} \mathrm{L}^{-1}\right)$ & 38.60 \\
\hline Magnesium (mg L $\left.{ }^{-1}\right)$ & 39.12 \\
\hline Copper $\left(\mathrm{mg} \mathrm{L}^{-1}\right)$ & 0.25 \\
\hline $\operatorname{Zinc}\left(\mathrm{mg} \mathrm{L}^{-1}\right)$ & 0.20 \\
\hline
\end{tabular}

The SW was applied manually, seven days before sowing, with the aid of a watering can, in a single dose, taking the utmost care to avoid wastewater outflow from the portion.

In the experimental area, the soybean was seeded, cultivar CD 214, Coodetec (Central Cooperative of Agricultural Research) of premature cycle, 117 days. Manual seeding was made, after harvesting the oats, with density of 15 seeds per linear meter spaced between lines of $45 \mathrm{~cm}$, providing a stand of 300,000 plants per hectare. Thus, in each portion were four rows of the crop. The two central lines were considered usable area and the two laterals as margin. The seeding was performed on December $13^{\text {th }}, 2007$.

Glyphosate was used for weed control, applied 10 days before sowing, and during the crop cycle the weed control was done manually when necessary. No other cultural treatments were performed in the soybean culture.

Three collections of percolate were made at 40; 72 and 117 DAS (days after sowing). The collector points of each lysimeter were open for samples collection. At each collection point of the percolate was a plastic recipient with a capacity of 8 liters and as the capacity was completed, it was transposed into another plastic recipient corresponding to each lysimeter to homogenize the percolate samples. Thereafter, the percolate volume was homogenized and quantified. Then, the samples were stored in plastic bottles of $1000 \mathrm{~mL}$ and sent to the Laboratory of Environmental Sanitation of the State University of West Paraná - UNIOESTE, Campus Cascavel, where it was determined the $\mathrm{pH}$, electrical conductivity, total nitrogen, nitrate and phosphorus. The methods used were: APHA, AWWA \& WEF (1998) and TEDESCO et al. (1995). The analysis of potassium, magnesium and calcium were performed using atomic absorption spectrophotometry flame.

The total rainfall occurred in the period of the experiment was $550.4 \mathrm{~mm}$. In Figure 1, it can be observed the rainfall distribution during the experiment. 


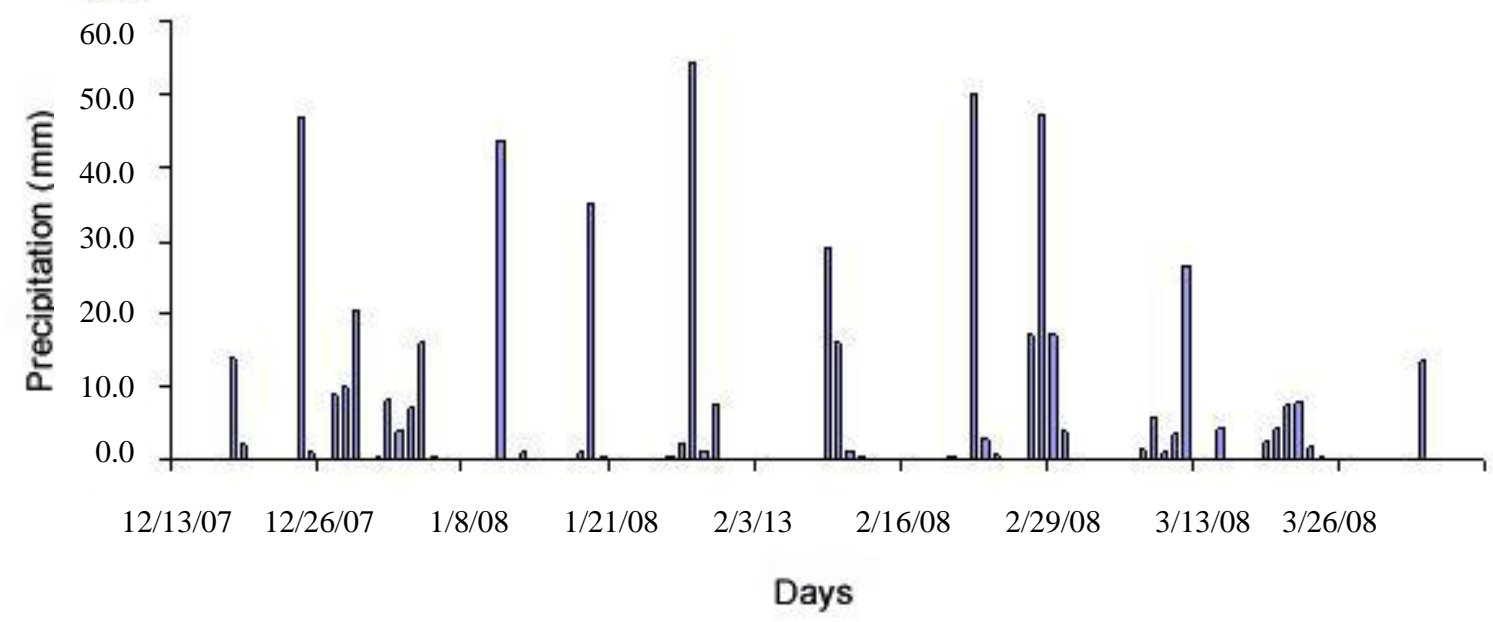

FIGURE 1. Distribution of rainfall occurred during the experiment.

The treatments were arranged in portions of the experimental area with three replications.

For the chemical analysis of the percolate, the experimental delineation was in randomized blocks in factorial scheme $(4 \times 2)$ and sub-portions in time, i.e., it was used four SW rates $(0 ; 100$; 200 and $300 \mathrm{~m}^{3} \mathrm{ha}^{-1}$ ), two levels of fertilization (with or without chemical fertilizer at sowing), in which the sub-portions were determined by three different collections (40; 72 and 117 DAS) with three replications.

Prior to the analysis of variance (ANOVA) it was made the descriptive data analysis and verification of normality of errors. For the parameters that did not show normal distribution of errors, were processed and subsequently submitted to analysis of variance.

The data were subjected to analysis of variance to verify its significance, for those who showed significance we proceeded a regression analysis.

\section{RESULTS AND DISCUSSION}

pH

The F value was significant only for days after seeding (DAS). For variables MF and SW, as well as their interactions, it was not identified statistical differences in $\mathrm{pH}$ values $\left(\mathrm{CaCl}_{2}\right)$ in aqueous extract of soil. The soil $\mathrm{pH}$ was not influenced by fertilization and the different SW rates applied. PELES (2007) observed no significant variations in soil $\mathrm{pH}$ values for different doses of pig slurry (0; 30; 60 and $\left.90 \mathrm{~m}^{3} \mathrm{ha}^{-1}\right)$ which confirms the results obtained in this study.

For the percolate, the $\mathrm{F}$ value was significant only for the DAS variable. It was set up a regression equation for days after sowing, which can be written as:

$$
p H=0.0029 D A S+6.9144, \mathrm{R}^{2}=0.70
$$

For the factors $\mathrm{SW}, \mathrm{MF}$ and interactions MF*SW, MF*DAS and SW*DAS, the F value was not significant at the $5 \%$ level.

The $\mathrm{pH}$ of the percolate did not vary as a function of treatment with $\mathrm{SW}$, and with or without addition of fertilizer. Similar results were found by SMANHOTTO (2008), CAOVILLA et al. (2005) and GOMES et al. (2004) who observed no significant differences in $\mathrm{pH}$ values for the percolate for treatment with SW and fertilization.

\section{Calcium}

The analysis of variance for the calcium $(\mathrm{Ca})$ contents in soil was significant for the cause of variation days after seeding (DAS). For the variables of fertilization (MF) and wastewater (SW) and 
their interactions, the $\mathrm{F}$ values were not significant. It was set the regression equation for SW, which is shown in Figure 2.

For the percolate, the Calcium values were significant for fertilization, for application rates of $\mathrm{SW}$ and for DAS. The calcium content in the percolate material was higher for treatments that were fertilized with the values of 55.51 and the non-fertilized was $46.53 \mathrm{mg} \mathrm{L}^{-1}$, and these were statistically different at $5 \%$ of probability. This may occurred because the formulated even if was not the basis of $\mathrm{Ca}$ showed a percentage of $\mathrm{Ca}$ in its composition which is around $11 \%$, and this factor contributed to the increased concentrations of $\mathrm{Ca}$ in the treatments that received fertilizer at sowing.

The calcium concentrations in percolate increased with SW rates (Figure 3). As the calcium in the soil is strongly adsorbed than ammonia, potassium and magnesium its leaching is not as intense and not actually gets to be worrying in terms of losses. In Figure 3 we can see that the calcium concentrations in the percolate increased according to the increase of SW rates, confirming that the organic waste increases leaching by the fact that the wastewater may cause rise in $\mathrm{pH}$ favoring mineralization, increasing $\mathrm{CO}_{2}$ release and, accordingly, leaching of $\mathrm{Ca}\left(\mathrm{HCO}_{3}\right)_{2}$.

In Figure 4 it can be observed that along the collections the $\mathrm{Ca}$ concentrations in the percolate reduced. Similar results were found in FREITAS et al., 2004, the calcium concentrations in the percolate of the lysimeters with application of swine wastewater, generally were lower in the end of the maize crop than initially.

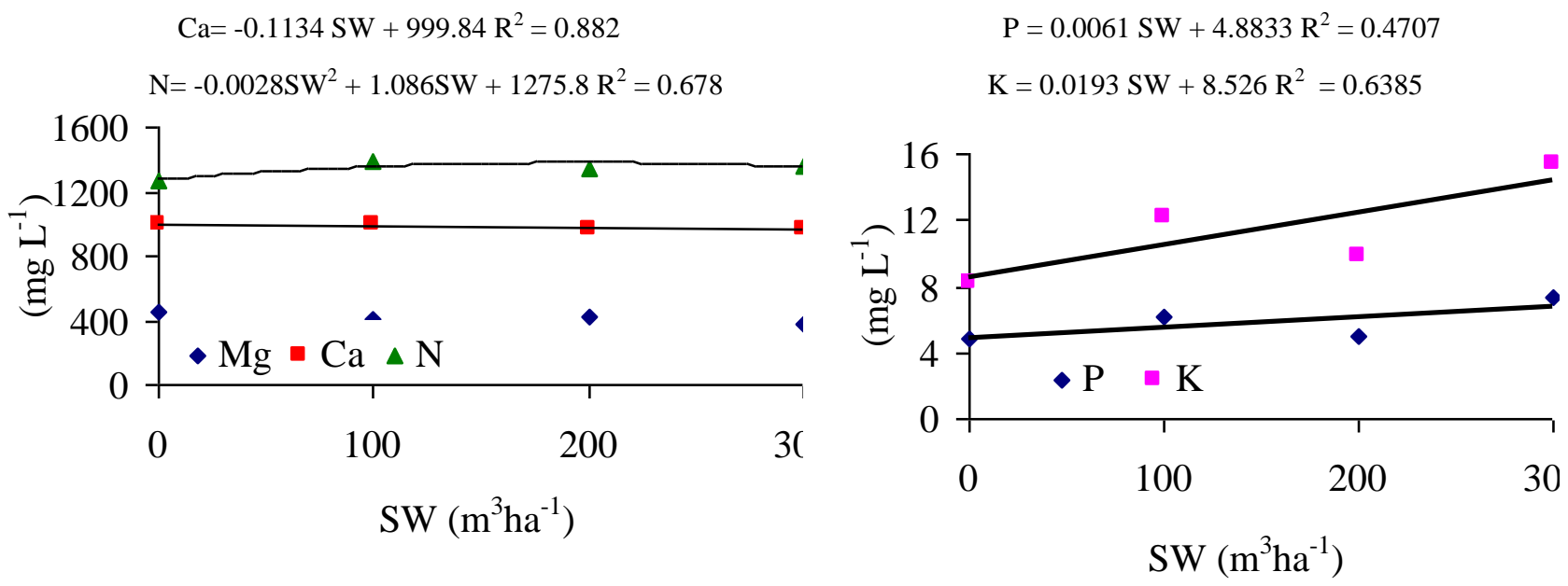

FIGURE 2. Concentrations $\left(\mathrm{mg} \mathrm{L}^{-1}\right)$ of chemical elements in the soil according to the different applied doses.

\section{Magnesium}

For the soil, the $\mathrm{F}$ was significant for DAS at $5 \%$ of probability, not being significant for other factors (MF and SW) as well as their interactions (MF*SW, MF*DAS, SW*DAS).

For the percolate, the $\mathrm{F}$ was not significant for any of the evaluated factors. I.e., the concentrations of magnesium in the percolate material were not affected by SW rate, or by fertilization, as well as their interactions and the dates of collections.

\section{Potassium}

For the soil, the $\mathrm{F}$ value was significant at the 5\% level of probability for the factors MF, SW and the interactions MF*SW. For the factor DAS and the interactions MF*DAS and SW*DAS, F was not significant.

The average concentrations of potassium in the soil showed a significant linear response $(\mathrm{p}<0.05)$ with the variable SW. The wastewater incorporated into the soil increased the availability 
of potassium in the soil, being higher for the higher rates of swine wastewater. The regression equation established for potassium contents in the soil according to rates of SW is showed in Figure 2.

Before the application of SW, the $\mathrm{K}$ content in the soil was $9.34 \mathrm{mg} \mathrm{dm}^{-3}$. It appears from Figure 2 that in the treatments without SW, the K contents in the soil were reduced, to those that received a rate of $100 \mathrm{~m}^{3} \mathrm{ha}^{-1}$ of $\mathrm{SW}$, in which a quantity equivalent to $6 \mathrm{~kg} \mathrm{ha}^{-1}$ was added, it was obtained an increase in the contents of $\mathrm{K}$ in the soil of $15.63 \%$. In treatments with a rate of $200 \mathrm{~m}^{3} \mathrm{ha}^{-1}$, the amount of $\mathrm{K}$ added was equivalent to $12 \mathrm{~kg} \mathrm{ha}^{-1}$, which caused an increase of $4.5 \%$ in the values of $\mathrm{K}$ in the soil. For treatments that received $300 \mathrm{~m}^{3} \mathrm{ha}^{-1}$ of $\mathrm{SW}$, the amount of $\mathrm{K}$ added was equivalent to $18 \mathrm{~kg} \mathrm{ha}^{-1}$, which caused an increase of $30.62 \%$ in the values of $\mathrm{K}$ in the soil.

For the percolate, the variance analysis was significant to the fertilization factor, SW and DAS, showing no significant interactions for SW and MF.

The treatments that received fertilizer at sowing had higher $\mathrm{K}$ concentrations in the percolate (133.48 $\mathrm{mg} \mathrm{L}^{-1}$ ), while the unfertilized showed lower values $\left(84.94 \mathrm{mg} \mathrm{L}^{-1}\right)$. This was due to the fact that $\mathrm{K}$ is a mobile element in the soil which is subject to leaching, and this will be greater the more significant is the presence in solution of anions with lower adsorption capacity. This greater leaching in treatments with chemical fertilizer at seeding occurred by the fact that the potassium used in fertilizer was applied as $\mathrm{KCl}$ (potassium chloride), and this nutrient when applied as $\mathrm{KCl}$, suffers greater leaching than when applied in $\mathrm{K}_{2} \mathrm{SO}_{4}$ (potassium sulfate) form, anion with greater absorptive capacity than $\mathrm{KCl}$, or $\mathrm{KAISiO}_{4}$ (kalsilite), which besides presents low water solubility contain $\mathrm{SiO}_{4}{ }^{-}$anion which is more strongly adsorbed by $\mathrm{H}_{2} \mathrm{PO}_{4}{ }^{-}$.

For the potassium concentrations in percolate material was possible to establish a linear regression model according to increasing rates of SW (Figure 3).

The potassium concentrations in the percolate material increased along the development cycle of the crop, allowing the adjustment of an increased linear regression model according to the dates of sampling (Figure 4).
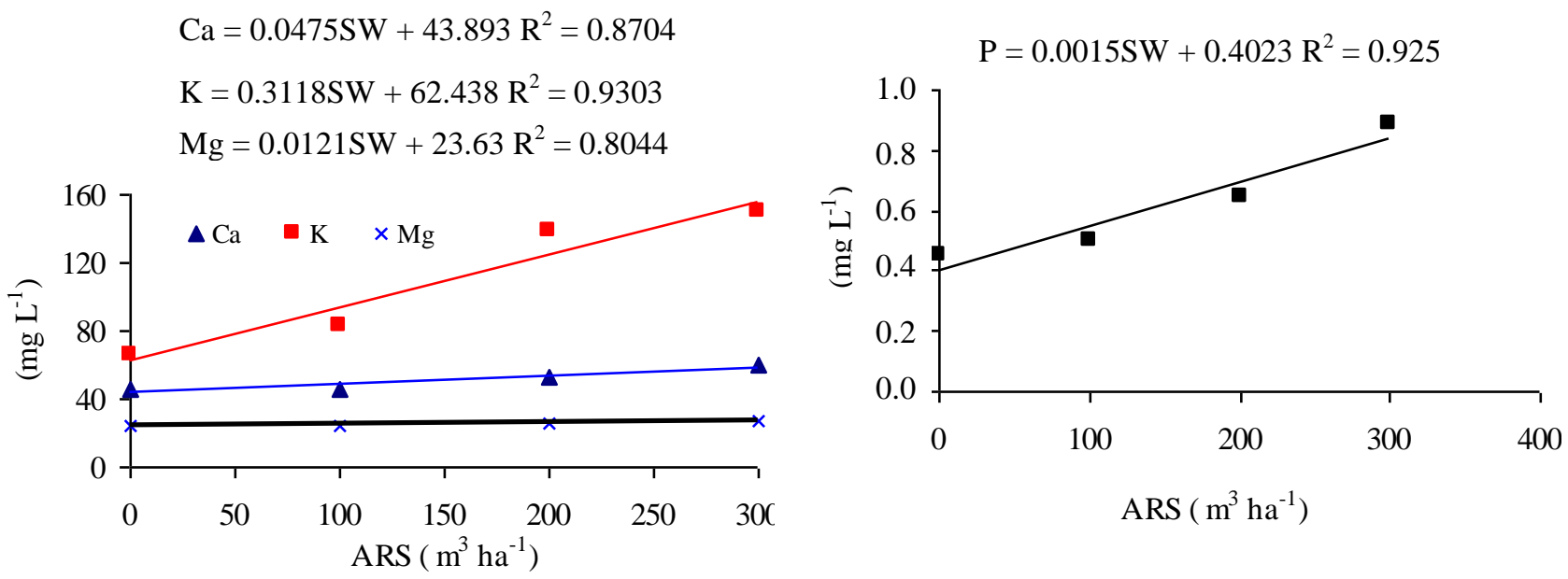

FIGURE 3. Concentrations $\left(\mathrm{mg} \mathrm{L}^{-1}\right.$ ) of percolate according to different applied doses.

\section{Phosphorus}

For the soil, the $\mathrm{F}$ values were significant at the 5\% level of probability for the factors SW, for the interactions of $\mathrm{MF}^{*} \mathrm{SW}$ and for DAS.

For the average levels of phosphorus in the soil, it was possible to establish a significant linear regression $(p<0.05)$ with variable $S W$. The regression equation established for the concentration of $\mathrm{P}$ in soil according to SW rates is presented in Figure 3. 
The average contents of $\mathrm{P}$ in the soil suffered an increase according to the application rates of SW. The highest value of $\mathrm{P}$ in the soil was $7.27\left(\mathrm{mg} \mathrm{dm}^{-3}\right)$, for the highest rate of $\mathrm{SW}$ applied $\left(300 \mathrm{~m}^{3} \mathrm{ha}^{-1}\right)$.

The obtained values are in agreement with PRIOR et. al. (2009), BERWANGER et. al. (2008), both found an increase in the rates of phosphorus in the soil due to the increase of application of SW rates.

The behavior observed in the present study can be observed in studies performed by QUEIROZ et al. (2004) who observed an increase in the content of available P in relation to the initial condition with application of SW, indicating an accumulation of this macro nutrient in the soil.

For the percolate, the phosphorus values were higher for the treatments that received fertilizer of 1.01 and $0.83 \mathrm{mg} \mathrm{L}^{-1}$ for the non-fertilized.

Figure 3 shows that the highest concentrations of phosphorus in the percolate were found in treatments with higher rate of SW. The regression model adjustable to phosphorus concentrations in the percolate was the increased linear (Figure 3).

The mobility of phosphorus in the soil is very small, and therefore the percolation losses in agricultural soils are considered insignificant (BASSO et al., 2005), due to that, it can be observed low concentrations of the element in the percolate.

BERTOL et. al. (2010) demonstrated that the soil that receives pig slurry provides greater susceptibility of the soil to phosphorus loss in relation to the soil that receives formulated with NPK. This means also that the transfer of phosphorus to the soil through liquid swine manure has a higher environmental risk than if the transfer were made by an inorganic source.

The variance analysis of phosphorus concentrations $\left(\mathrm{mg} \mathrm{L}^{-1}\right)$ in the percolate material to the SW unfolding within each level of fertilization was significant for the treatment that received fertilization.

The results corroborate to those obtained by DOBLINSKI et. al. (2010) which, in applying SW in soil cultivated with beans, have found that the losses of total phosphorus in the soil were increased as the doses of applied SW increased, being higher for the higher rate of $200 \mathrm{~m}^{3} \mathrm{ha}^{-1}$. Also, from the control this amount was increased linear.

The highest concentrations of phosphorus in the percolate for the unfolding of SW with fertilizer at sowing were found in treatments with higher rate of SW. The regression model adjusted for phosphorus concentrations in the percolate were increased linear.

The regression model adjustable to phosphorus concentrations in the percolate according to the collections was the quadratic (Figure 4).

Similar results were found by BERWANGER et. al. (2008), in which concentrations of total phosphorus in the percolate, with application of $0 ; 520$ and $1.040 \mathrm{~m}^{3} \mathrm{ha}^{-1}$ in five years, the swine wastewater in maize culture do not depend on the applied rates. The highest concentrations of phosphorus were observed at 79 days after application of the manure, and the increases in total phosphorus reached 1.2 and 2.9 times the cumulative quantities of 520 and $1,040 \mathrm{~m}^{3} \mathrm{ha}^{-1}$, in relation to where the SW was not applied.

The percolation of phosphorus in the soil profile after application of SW is small. EGHBALL et al. (1990), applying $60 \mathrm{~kg} \mathrm{ha}^{-1}$ of phosphorus in strips, noted that the movement of phosphorus in profile was only $4 \mathrm{~cm}$ in three different soil types. However, the movement in depth of the element may increase when combining high doses of mineral fertilizer with addition of organic waste.

BASSO et al. (2005) reported that concentrations of phosphorus from 0.2 to $0.3 \mathrm{mg} \mathrm{L}^{-1}$ are considered ideal in the percolate water for a good plant development. 


\section{Nitrogen}

The $\mathrm{F}$ values were significant for the factors: fertilizer, wastewater, collection dates and interactions $\mathrm{MF}^{*} \mathrm{SW}$ and $\mathrm{MF} * \mathrm{DAS}$ for $\mathrm{N}$ in the soil.

It was adjusted a regression model for the $\mathrm{N}$ content in the soil $\left(\mathrm{mg} \mathrm{dm}^{-3}\right)$ for the dependent variable SW (Figure 2). SAMPAIO et al. (2010) and CAOVILLA et al. (2005) observed similar results in a study on the same soil, where the concentration of total nitrogen decreased as a result of volatilization of ammonia resulting from the application of SW.

For nitrogen contents in the soil, depending on the days after sowing, the regression model established was the increased linear, indicating that the nitrogen content in the soil increased during the experiment.

For the percolate, the concentrations of total nitrogen were not influenced by the implementation of SW, or by fertilization. Similar results were found by SMANHOTTO (2008) when applied SW in soils cultivated with soybeans, in which observe no significant differences in the concentrations of nitrogen in the percolate with application of swine wastewater and fertilizer as well as for SW fertilizer interaction.

AGUIAR et al. (2006) found low total nitrogen content in the percolate after the application of cattle waste and rice straw and indicate that the reduction of the nutrient in the soil has, as its main cause, not the leaching, but the gaseous form through the mineralization process and volatilization respectively.

Whereas the concentration of total nitrogen of SW applied to the soil was $887 \mathrm{mg} \mathrm{L}^{-1}$, the maximum value found in the percolate was $0.72 \mathrm{mg} \mathrm{L}^{-1}$, the leaching losses were small. Discordant results found by BOEIRA et al. (2002), wherein the application of high doses of sewage sludge to soil, however, may liberate mineral nitrogen above the needs of a growing, with potential risk of leaching of nitrate in the soil.
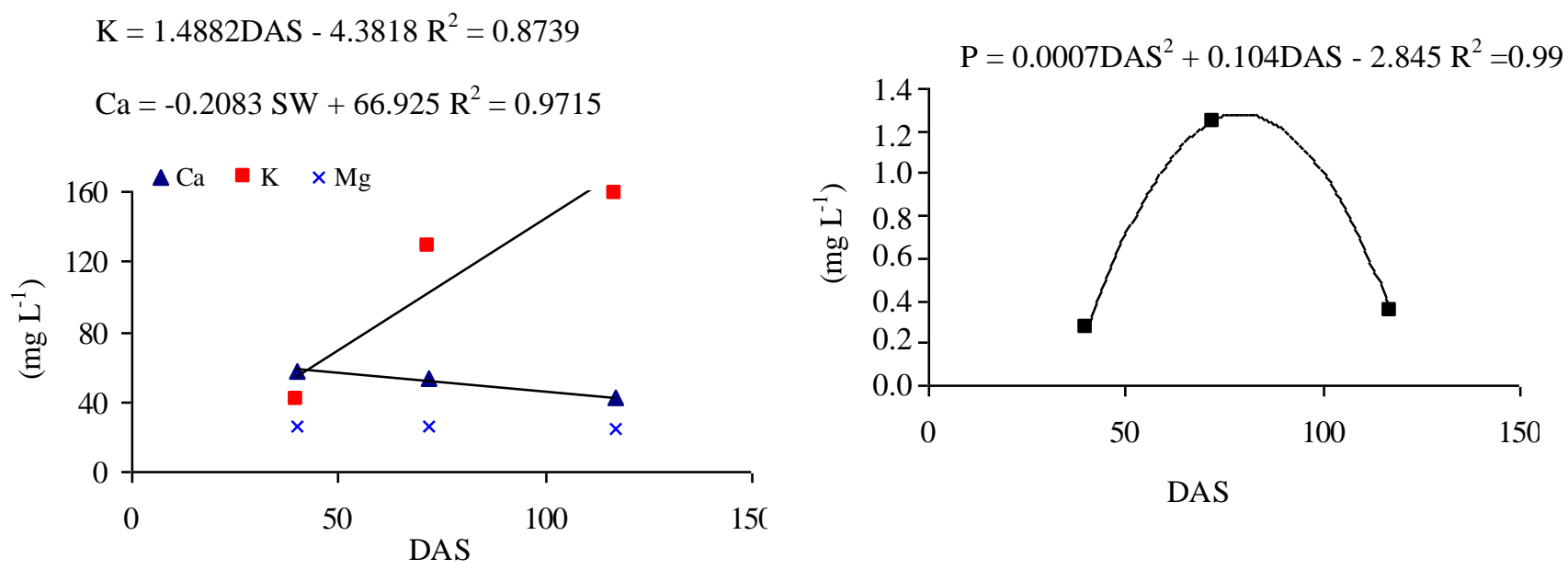

FIGURE 4. Concentrations $\left(\mathrm{mg} \mathrm{L}^{-1}\right)$ in the percolate according to different applied doses.

The regression model established was the increased linear, indicating that the nitrogen content in the percolate increased through the experiment.

\section{Soybean culture productivity}

It was found that $\mathrm{F}$ was not significant for fertilization, $\mathrm{SW}$ and for $\mathrm{SW}$ interaction fertilization. The factors fertilization and SW rates did not influence the productivity in $\mathrm{kg} \mathrm{ha}^{-1}$ of the soybean crop. Discordant results were found by DRUMOND et al. (2006), who observed difference in dry matter production in grazing Tifton-85 with SWn application doses of 0; 50; 100 and $200 \mathrm{~m}^{3} \mathrm{ha}^{-1}$. 
Also the $\mathrm{F}$ value was not significant to $\mathrm{SW}$ and $\mathrm{MF}$ as well as to $\mathrm{MF} * \mathrm{SW}$ interaction. The number of seeds per plant was not influenced by the application of SW and by fertilization or not at sowing.

\section{CONCLUSIONS}

For the conditions of the experiment, the application of SW and fertilization at sowing did not significantly influence the values of $\mathrm{pH}$ in the percolate; however, these values were statistically different for the collection dates.

The Ca contents in the soil were not affected by SW application and fertilizer; however, the values were different for the periods of sampling.

The $\mathrm{P}, \mathrm{K}$ and $\mathrm{Ca}$ contents in the percolate increased with increasing rates of $\mathrm{SW}$ and suffered alterations of values over the collections.

The $\mathrm{N}$ in the percolate was not influenced by the application of SW; however, increased over the collections.

The soybean productivity was not influenced by the application of swine wastewater as well as for fertilization.

\section{REFERENCES}

AGUIAR, M.I.; LOURENÇO, I.P.; OLIVEIRA, T.S.; LACERDA, N.B. Perda de nutrientes por lixiviação em um ARGISSOLO Acinzentado cultivado com meloeiro. Revista Brasileira de Engenharia Agrícola e Ambiental, Campina Grande, v.10, n.4, p.811-819, 2006.

AMERICAN PUBLIC HEALTH ASSOCIATION. Standard methods for the examination of water and wastwater. 19th ed. Washington: APHA, AWWA, WEF. 1995.

ANAMI, M.H.; SAMPAIO, S.C.; SUSZEK, M.; GOMES, S.D.; QUEIROZ, M.M.F. Deslocamento miscível de nitrato e fosfato proveniente de água residuária da suinocultura em colunas de solo. Revista Brasileira de Engenharia Agrícola e Ambiental, Campina Grande, v.12, n.1, p.75-80, 2008.

BARROS, F.M.; MARTINEZ, M.A.; NEVES, J.C.L.; MATOS, A.T.; SILVA, D. D.

Características químicas do solo influenciado pela adição de água residuária da suinocultura. Revista Brasileira de Engenharia Agrícola e Ambiental, Campina Grande, v.9, p.47-51, 2005. Suplemento.

BASSO, C.J.; CERETTA, C.A.; POLETTO, R.D.N.; GIROTTO, E. Dejeto líquido de suínos: II perdas de nitrogênio e fósforo por percolação no solo sob plantio direto. Ciência Rural, Santa Maria, v.35, n.6, p.1305-1312, 2005.

BERTOL, O. J.; RIZZI, N. E.; FAVARETTO, N.; LANA, M. C. Perda de fósforo via escoamento superficial no sistema plantio direto sob adubação mineral e orgânica. Scientia Agricola, Piracicaba, v.67, n.1, p.71-77, 2010.

BERWANGER, A.L.; CERETTA, C.A.; RHEINHEIMER, D.S. Alterações do fósforo no solo com aplicação de dejeto líquido de suínos. Revista Brasileira de Ciência do Solo, Viçosa, v.32, p.25252532, 2008.

BOEIRA, R.C.; LIGO, M.A.V.; DYNIA, J.F. Mineralização de nitrogênio em solo tropical tratado com lodos de esgoto. Pesquisa Agropecuária Brasileira, Brasília, v.37, n.11, p.855-862, 2002.

CAOVILLA, F.A.; SAMPAIO, S.C.; SMANHOTTO, A.; NOBREGA, L.H.P.; QUEIROZ, M. M. F. de; GOMES, B. M. Características químicas de solo cultivado com soja e irrigado com água residuária da suinocultura. Revista Brasileira de Engenharia Agrícola e Ambiental, Campina Grande, v.14, p.692-697, 2010. 
CAOVILLA, F.A.; SAMPAIO, S.C.; PEREIRA, J.O.; VILAS BOAS, M.A.; GOMES. B.M.; FIGUEIREDO, A.C. Lixiviação de nutrientes proveniente de águas residuárias em colunas de solo cultivado com soja. Revista Brasileira de Engenharia Agrícola e Ambiental, Campina Grande, v.9, p.283-287, 2005. Suplemento.

DAL BOSCO, T.C.; SAMPAIO, S.C.; OPAZO, M.A.U.; GOMES, S.D.; NÓBREGA, L.H.P. Aplicação de água residuária de suinocultura em solo cultivado com soja: cobre e zinco no material escoado e no solo. Engenharia Agrícola, Jaboticabal, v.28, p.699-709, 2008.

DIETER, J.; SMANHOTTO, A.; PRIOR, M.; SILVESTRO, M.; SAMPAIO, S.C. Comportamento de Sais lixiviados em lisímetros oriundos da aplicação da Água Residuária de Suinocultura. In: CONGRESSO BRASILEIRO DE ENGENHARIA SANITÁRIA E AMBIENTAL, 24., 2007, Belo Horizonte. Anais... Belo Horizonte: Associação Brasileira de Engenharia Sanitária e Ambiental, 2007, p. 1-8.

DOBLINSKI A, F.; SAMPAIO, S.C.; SILVA, V.R. da; NÓBREGA, L.H.P.; GOMES, S. D.; DAL BOSCO, T.C. Nonpoint source pollution by swine farming wastewater in bean crop. Revista Brasileira Engenharia Agrícola e Ambiental, Campina Grande, v.14, n.1, p.87-93, 2010.

DRUMOND, L.C.D.; ZANINI, J.R.; AGUIAR, A.P.A.; RODRIGUES, G.P.; FERNANDES, A.L.T. Produção de matéria seca em pastagem de tifton 85 irrigada, com diferentes doses de dejeto líquido de suíno. Engenharia Agrícola, Jaboticabal, v.26, n.2, p.426-433, 2006.

EGHBALL, B.; SANDER, D.H.; SKOPP, J. Diffusion, adsorption and predicted longevity of banded phosphorus fertilizer in three soils. Soil Science Society American Journal, Madison, v.54, n.4, p.1161-1165, 1990.

EMBRAPA. EMPRESA BRASILEIRA DE PESQUISA AGROPECUÁRIA. Centro Nacional de Pesquisa de Solos. Sistema brasileiro de classificação de solos. 2.ed. Brasília, 2006. 412 p.

FAO. Lisimeters. Roma, 1982. 68 p. (Irrigation and Drainage Paper, 39)

FREITAS, W.S.; OLIVEIRA, R.A.; CENCON, P.R.; PINTO, F.A.; GALVÃO, J.C.C. Efeito da aplicação de água residuária de suinocultura sobre a produção de milho para silagem. Revista brasileira de Engenharia Agrícola e Ambiental, Campina Grande, v.8, n.1, p.120-125, 2004.

FRIGO, E. P. Uso de água residuária de suinocultura na cultura do milho. 2008. 85 f. Tese (Doutorado em Agronomia) - Faculdade de Ciências Agronômicas, Universidade Estadual Paulista, Botucatu, 2008.

GOMES, E.R.S.; SAMPAIO, S.C.; CORRÊA, M.M.; VILAS BOAS, M.A.; ALVES, L.F.A.; SOBRINHO, T.S. Movimento de nitrato proveniente de água residuária em colunas de solos. Engenharia Agrícola, Jaboticabal, v.24, n.3, p.557-568, 2004.

PELES, D. Perdas de solo, água e nutrientes sob aplicação de gesso e dejeto líquido de suínos. 2007. 97 f. Dissertação (Mestrado em Ciência do solo) - Universidade Federal do Paraná, Curitiba, 2007.

PELISSARI, R.A. Z.; SAMPAIO, S.C.; GOMES, S. D.; CREPALLI, M.D.A.S. Lodo têxtil e água residuária da suinocultura na produção de mudas de Eucalyptus grandis (W, Hill ex Maiden). Engenharia Agrícola, Jaboticabal, v.29, n.2, p.288-300, 2009.

PRIOR, M.; SMANHOTTO, A.; SAMPAIO, S.C.; NOBREGA, L.H.P.; OPAZO, M.A.U.; DIETER, J. Acúmulo e percolação de fósforo no solo devido à aplicação de água residuária de suinocultura na cultura do milho (Zea mays L.). Revista Brasileira de Tecnologia Aplicada nas Ciências Agrárias, Guarapuava, v.2, n.1, p.89-96, 2009.

PRIOR, M. Efeito da água residuária de suinocultura no solo e na cultura do milho. $2008.120 \mathrm{f}$. Tese (Doutorado em Agronomia) - Faculdade de Ciências Agronômicas, Universidade Estadual Paulista, Botucatu, 2008. 
QUEIROZ, F.M.; MATTOS, A.T.; PEREIRA, O.G.; OLIVEIRA, R.A. Características químicas de solo submetidos ao tratamento com esterco líquido de suínos e cultivados com gramíneas forrageiras. Ciência Rural, Santa Maria, v.34, n.5, p.1487-1492, 2004.

SAMPAIO, S. C.; CAOVILLA, F.A.; OPAZO, M.A.U.; NÓBREGA, L.H.P.; SUSZEK, M.; SMANHOTTO, A. Lixiviação de íons em colunas de solo deformado e indeformado. Engenharia Agrícola, Jaboticabal, v.30, n.1, p.150-159, 2010.

SAMPAIO, S.S.; FIORI, M.G.S.; OPAZO, M.A.U.; NÓBREGA, L.H.P. Comportamento das formas de nitrogênio em solo cultivado com milho irrigado com água residuária da suinocultura. Engenharia Agrícola, Jaboticabal, v.30, n.1, p.138-149, 2010.

SMANHOTTO, A. Efeito da aplicação de água residuária de suinocultura em solo cultivado com soja. 2008. 100 f. Tese (Doutorado em Agronomia) - Faculdade de Ciências Agronômicas, Botucatu, Universidade Estadual Paulista, 2008.

SMANHOTTO, A.; SOUSA, A.P; SAMPAIO, S.C.; NÓBREGA, L.H.P.; PRIOR, M. Cobre e zinco no material percolado e no solo com a aplicação de água residuaria de suinocultura em solo cultivado com soja. Engenharia Agrícola, Jaboticabal, v.30, n.2, p.347-357, 2010.

TEDESCO, M. J.; GIIANELLO, C.; BISSANI, C. A.; BOHNEM, H.; VOLKWEISS, S. J. Análise de solo, plantas e outros materiais. Porto Alegre: UFRGS, 1995. 174 p. 